\title{
Strategic Policy on the Development of Higher Education in China
}

\author{
Bing Zhao* \\ School of Accounting and Finance, Canvard College, Beijing Technology and Business University, Beijing, 101118, China.
}

\begin{abstract}
Asian Universities rank high in the global universities, while western universities decline due to the the quality of higher education. There are several reasons owing to the rise of Asian universities including the increase in the enrollment, active research circumstances, the Asian culture of learning, etc. China has the long history of education and the earliest education can be traced back to Yu period (2257-2208 BC). Then, education in China evolves according to different dynasties and country policies. What is worth to mention is that Chinese government plays an essential role in the development of higher education in China like supplying financial support, making 985 and 211 program, and enlarging of enrollment.

Keywords: higher education, Asian education, strategic development
\end{abstract}

\section{Introduction}

Each time global university rankings are released, the media invariably points to the rapid rise in these ranking of Asian universities with alarm, bemoaning a decline of the quality of higher education in the more established systems in Western countries (Rizvi, 2016, p.519). According to the Times Higher Education (THE) in 2018, Peking University has risen two places to joint 27th, which ranks the same with New York University and the University of Edinburg and ahead of the Karolinska Institute. Tsinghua University has climbed five places to 30th, overtaking the University of Melbourne, Georgia Institute of Technology, LMU Munich and Ecole Polytechnique Federale de Lausanne. Both those Chinese institutions have improved in terms of their reputations for teaching and research this year - meaning that there are now three Asian universities in the top 30 of the ranking for the first time under the current methodology.

\section{The rise of Asian universities}

Rizvi (2016) has analyzed how the rise of Asian education is understood in western countries like the USA, the UK, and Australia. Firstly, the increase in the enrollment in undergraduate programs has been explosive across Asia. In most Asian countries, both public and private investment in higher education has more than doubled over past two decades. In addition, the basic education also contributes to the growth in higher education participation rates. Most students than ever are now graduating from secondary schools and seeking to continue their education, thinking this to be necessary for improved career and life opportunities. Secondly, more and more universities throughout Asia have become research active since research is viewed as a major driver of economic productivity. This has led universities throughout Asia to pressure their faculty, not only to conduct high-level research, but also to publish widely. Thirdly, the Asian culture of learning could also explain the rise of Asia. The recent success is due to the commitment to Confucian principles that include respect for authority, hard work, and the responsibilities to preserve the unity of the Chinese state. Therefore, education plays a major role in developing citizens who are culturally confident and globally strategic. Finally, the economic rise in Asia form a solid foundation for the development of higher education. Confucian philosophy of society, based on the principles of order and stability as well as deference to superiors had the influence across most of East Asia, Vietnam, and Singapore.

\section{The retrospect of education in China}

Since China's history and civilization has been lasting till today, there is still connection between ancient and modern education like the reliance of bureaucracy and influence of Confucianism. It is necessary to review the history of China's education and culture origins. In terms of relationship between one and oneself, one and others, and one nature in the Chinese and Anglo-Saxon culture, the Chinese culture emphasized self-denial and observes proprieties and asceticism, while the Anglo-Saxon cultures treasures individualism. (Yang, 2013, p.87). The five orders of constant virtues of benevolence, righteousness, propriety, wisdom, and fidelity are central to the Chinese culture. Anglo-Saxon believes that "All men are created equal." and pursue for the human nature. Chinese culture exclusively focuses on human nature. (Yang, 2013, p.87). The earlier Chinese education system was established during Yu period (2257-2208 BC) when the imperial central academy was named Shangyang. From Han Dynasty, government

Copyright (C) 2020 Bing Zhao

doi: $10.18282 / 1-e . v 9 i 4.1690$

This is an open-access article distributed under the terms of the Creative Commons Attribution Non-Commercial License (http://creativecommons.org/licenses/by-nc/4.0/), which permits unrestricted non-commercial use, distribution, and reproduction in any medium, provided the original work is properly cited. 
viewed the education institution called "Taixue" as the place to train talents and select political personnel. This practice was the beginning of the strong Chinese tradition - higher education aiming at preparing would-be officials for the state- for more than 2000 years (Yang, 2013, p.88). Therefore, the earlier education institution in China is totally different from European universities which are autonomy and academic freedom. The education reform hasn't started until earlier 20th century when China saw dramatic changes of social systems and successive efforts of education reforms. The old backward feudalist system was overthrown, and the country encountered a painful and destructive period of wars. The struggle of different political ideologies and military groups covered the whole country and last for half a century. (Xu, 2005, p.83).

Since the foundation in 1949, similar to the former Soviet Union, at a system level, except for a very few comprehensive universities, the vast majority of higher educational institutions were practically categorized according to the social professional or vocational fields. All those types of specialties were further divided into numbers of educational programs. Each higher education institution established and reorganized their undergraduate curriculum in accordance with the national criteria for the establishment of fields or disciplines, most of which were concerned with utilitarian and practical subjects. (Huang, 2015, p.206). At the end of devastating Cultural Revolutionary Movement from 1966-1976, the president Deng Xiaoping came up with the strategic policy of "Reform and Opening up" in 1978, aiming to develop our economy. Government realized that higher education system was inadequate to meet the needs of the economy. At the same time, president Deng also demonstrated the strategy of "groping for stones to cross the river," in which ideologies are set aside and traditional differences in education values are shelved. What stressed most is the possible educational contribution to economic growth. (Yang, 2013, p.90). Moreover, under the globalization trend in the worldwide and market-oriented economic reform, education reforms have been carried out in the early 1980s, which have been characterized by decentralization and marketization. (Ngok, 2008, p. 548).

In the 1990s, important strategies of developing China's higher education have been implemented. Firstly, the central government issued the 211 Project in 1995, aiming to establish 100 key universities in China by the twenty-first century. It has also planned to finance Peking University and Tsinghua University intensively with the purpose of enabling the two universities to reach or approach a higher level in the world and become world-class institutions. (Huang, 2015, p.207). "21" means facing 21st century and "1" represents about 100 universities. From the year of 1995, government provided extra financial support to these universities in addition to the original annual funds. Currently, the first stage of "Project 21-1" (1995-2000) ended, and the second (2001-2005) is on the way. According to an official report of the first phase, the total amount of "Project 21-1" funds raised and input during 1996-2000 reached approximately US\$2,200,000,000. The papers published in SCI, EI and ISTP of the universities within "Project 21-1" increased by 94\% during the same period. (Song \& Li, 2005, p.127).

Along with the "Project 21-1", the Chinese government started another plan of improving higher education- "Project 98-5", which derives from the speech by former President of China, Jiang Zemin in the 100th anniversary of Peking University. (Song \& Li, 2005, p.127). He declared that in order to accelerate modernization, China should build some world-level universities (Jiang, 1998). Therefore, a plan of constructing world-class universities named "98-5" was put forward. Here "98" represents the year of 1998, and "5" represents the month of May. The goal of "Project 98-5" is to make a few famous universities world-class ones by favorable financial policies. From July 1999 to November 1999, nine universities were selected to be included in the 985 Project as the first group. They are Peking University, Tsinghua University, Zhejiang University, Fudan University, Shanghai Jiaotong University, Nanjing University, Harbin institute of Technology and Xi'An Jiaotong University. In October 2009, these nine universities agreed to create a Chinese counterpart to the ivies and formed the C9. Modelling on the Ivies and Russel Group universities, the C9 are committed to the highest levels of academic excellence in teaching and research. (Huang, 2015, p.207). From the world-class university ranking in 2018, several of C9 has been listed within 100 tops. For each 985 university, there are three-step strategy: the first step is to become a comprehensive, research-oriented, internationalized higher education institution by 2010; the second step is to stand in the top 100 universities in the world universities rankings by 2020; and the third step is to achieve its overall world-class status by the middle of the twenty-first century. (Huang, 2015, p.208). In order to achieve the goal, the key strategies include improving faculty quality, strengthening fundamental sciences, encouraging interdisciplinary research, promoting internationalization and serving the national needs.

\section{The analysis of higher education in China}

In the quest for development of higher education and world-class universities, Chinese government plays the essential role in making the progress. Both central government and local authorities have collaborated with each other to supply financial support for building world-class research universities. Normally, when a university is selected to be included in the 985 Project, the Ministry of Education signs a collaborative agreement with the local government which promises to allocate a matching sum of funding to the university. (Huang, 2015, p.208). In the first phase of 98-5 Project, central government allocated more than half of funding to the universities, while in the second phase it is local authorities who add more than half of the funding to the $98-5$ universities, during the process of which local authorities play more and more important role in the developing higher education.

In addition, massification of higher education is also driven by the government, especially central government, which is keen on "revitalizing China through developing science and education" (kejiaoxingguo). (Ngok, 2008, p.548). In 1999, in order to ease unemployment pressures and meet the increasing demand for higher education, the Chinese government decided to rapidly expand the higher education by enlarging the enrolment scale of postsecondary students. As a response to the government's policy of enlarging enrolment of students, all universities in China, including the top-tier ones of Peking University, Tsinghua University, expanded their scale of enrolment. Therefore, in 1999, the number of student enrolled in the regular higher education institutions hit 1.597 million, representing a 47 percent increase from 1.084 million in 1998. After that, China's higher education has entered an era of swift growth. The rapid research students' enrollment also could explain the massification of higher education. The number 
of research students increased from 92,200 in 1999 to 364,800 in 2005 . There is no doubt that under the state-controlling model of university governance in China, the main momentum of the expansion of university education is from the government. (Ngok, 2008, p. 550). The rapid growth of higher education system is the result of the expansion of the existing universities, rather than of the development of community colleges and vocational colleges as happened in other industrialized countries. On the top of the state administrative power, market force has also had a role to play in the expansion of education scale, though it is very marginal. From early 1980s, the Chinese government began to encourage business enterprises, private institutions, individuals and even foreign institutions to support academic programs in existing educational institutions or to sponsor educational institutions (Ngok, 2008, p.551). Then, different types of colleges run by non-state sector have emerged and their number grown rapidly.

There are many problems facing Chinese universities to become world-class research universities, though a great deal of achievement has been accomplished and several of them have already raised their level at global ranking systems in a speedy and steady way. (Huang, 2015, p.212). Firstly, in the definition of a university, an important idea is the notion of academic freedom, of which the earliest documentary evidence came from early in the life of the "first" university. (Yang, 2013, p.87). Academic freedom is now recognized internationally as a definitive feature of a university. In other societies and cultures, academic freedom has proved to be a great challenge to higher education specifically and to the wider society in general, especially in many nonwestern societies where democratic culture traditions have been historically lacking. (Yang, 2013, p.87). Though China now has the world's biggest sector of university education and is on his way of building world-class universities, the further development of China's higher education is constrained heavily by its existing model of university governance. (Ngok, 2008, p.558). The central elements of academic life including admission of students, the curriculum, the criteria for the award of degrees, the promotion of academic staff, and the basic direction of the academic work of the institution, are not controlled by academic community composed by professors. Seemingly, the autonomies stipulated in the Higher Education Law enacted in 1998, the autonomies enjoyed by universities include admission of students, establishing of academic specialties, choice of teaching plan and textbooks, research and development, external cooperation, and internal setup and staff recruitment are less effective in reality. For example, the Ministry of Education controls the total intake of university students nation-wide rather than university themselves, which means that the state-relationship inherited from the planned economy has not been changed substantially. The next problem is that the assessment of application forms in most cases is not based on the quality of the research proposals but on the social connections and background of the applicants. (Ngok, 2008, p.561)

The Chinese path to building a world-class university is characterized with a top-down policy, accompanied by the growth in the amount of funding from both national government and especially from local authorities on few selected elite universities. (Huang, 2015, p.213). Public resources are concentrated on the most excellent universities. Both the projects of 211 and 985 focus on boosting the quality of a selected few Chinese universities, regardless of widespread public concern that equal opportunities for institutional and individual student development are not being provided.

\section{Conclusion}

The rise of higher education in Asian country is inspiring, which arouse fear and anxiety in western country. There are some aspects contributing the rise of higher education in Asia like the increase in the enrollment, active research circumstances, and the Asian culture of learning. The universities in China also made such great progress in the global university rank. In addition to the long history of China, government exerts great influence in the development of higher education in China including supplying financial support, making 985 and 211 program, and enlarging of enrollment. However, there are still some problems of higher education in China like academic freedom, university autonomy, and the criteria for the award of degrees. In order to become firsttop universities, China has a long to way to go.

\section{Reference}

[1]Huang, F. (2015). Building the world-class research universities: A case study of china. Higher Education, 70(2), $203-215$. doi:10.1007/s10734-015-9876-8

[2]Li, J. (2012). World-class higher education and the emerging Chinese model of the university. Prospects, 42(3), $319-339$. doi:10.1007/s11125-012-9241-y

[3]Ngok, K. (2008). Massification, bureaucratization and questing for "world-class" status: Higher education in china since the mid-1990s. The International Journal of Educational Management, 22(6), 547-564. doi:10.1108/09513540810895453

[4]Rizvi, F. (2016). Policy responses to the rise of Asian higher education: A postcolonial analysis, The Handbook of Global Education Policy, First Edition.Song, G., \& Li, L. (2005). The major measure in constructing world-class universities in china-the "project 98-5". KEDI Journal of Educational Policy, 2(2)

[5]Xu, S. (2005). Impacts of globalization on higher education reform in china: A trend of decentralization and autonomy. Educational Research for Policy and Practice, 4(2), 83-95. doi:10.1007/s10671-005-3363-4

[6]Yang, R. (2013). Indigenizing the western concept of university: The chinese experience. Asia Pacific Education Review, 14(1), 85-92. doi:10.1007/s12564-013-9254-0

[7]Yang, R., \& Welch, A. (2012). A world-class university in china? the case of Tsinghua. Higher Education, 63(5), 645-666. doi:10.1007/s10734-011-9465-4 